\title{
Positive inversion of extensional footwalls in the southern Serra do Espinhaço, Brazil - insights from sandbox laboratory experiments
}

\author{
CAROLINE J.S. GOMES ${ }^{1}$, MARCELO A. MARTINS-NETO ${ }^{1}$ and VALÉRIA E. RIBEIRO ${ }^{2}$ \\ ${ }^{1}$ Universidade Federal de Ouro Preto - Escola de Minas - Departamento de Geologia \\ Morro do Cruzeiro s/n, 35400-000 Ouro Preto, MG, Brasil \\ ${ }^{2}$ Companhia Vale do Rio Doce - Departamento de Ferrosos Sul \\ Serra do Esmeril s/n, 35900-900 Itabira, MG, Brasil \\ Manuscript received on November 11, 2004; accepted for publication on August 25, 2005; \\ presented by BENJAMIN B. BRITO NEVES
}

\begin{abstract}
Analogue experiments were carried out to get insights into the processes governing positive inversion during the foreland propagating thrust tectonics in the southern Serra do Espinhaço, a Brasiliano/Panafrican foldthrust belt in southeast Brazil. In particular, model listric half-grabens were inverted by applying contractional displacement to the footwall blocks. We investigated two different inversion conditions in listric half-grabens: (i) extensional and contractional detachments at the same level and (ii) at different positions. The models revealed that the development of a forward-breaking thrust system occurs in the basin synrift deposits, by contractional translation of the extensional footwall block when the extensional and contractional master faults do not coincide. Our experiments show the tectonic imbrication between basement and synrift sequences which characterizes the southern Serra do Espinhaço, and support the location in the eastern mountain range domain of the Espinhaço rift master fault system, which is not exposed at the surface.
\end{abstract}

Key words: experimental modeling, inversion tectonics, footwall block, Espinhaço Basin, different detachment levels.

\section{INTRODUCTION}

The southern Serra do Espinhaço, a north-south trending, nearly $300 \mathrm{~km}$ long mountain range, lies in the external portion of the Late Neoproterozoic Araçuaí belt, a Brasiliano/Panafrican orogenic belt that formed on the eastern margin of the São Francisco craton, in southeastern Brazil (Fig. 1). The Serra do Espinhaço is a west-verging thrust-fold belt originated by positive inversion of pre-existing extensional structures. The architecture of these

Correspondence to: Caroline Janette Souza Gomes E-mail: caroline@degeo.ufop.br faults is still a matter of debate. According to Dussin and Dussin (1995), the inverted basin was rather symmetrical, with opposite-dipping boundary faults, and Martins-Neto (1998, 2000) proposed a rift architecture developed above a west-dipping master fault located in the eastern portion of the Espinhaço range. In this case, a stimulating hypothesis suggested by the dominant westward vergence of the Brasiliano/Panafrican event is that basin inversion may have occurred by translation of extensional footwall blocks over newly formed lowangle thrust faults (Fig. 2).

The aim of this study is to experimentally inves- 


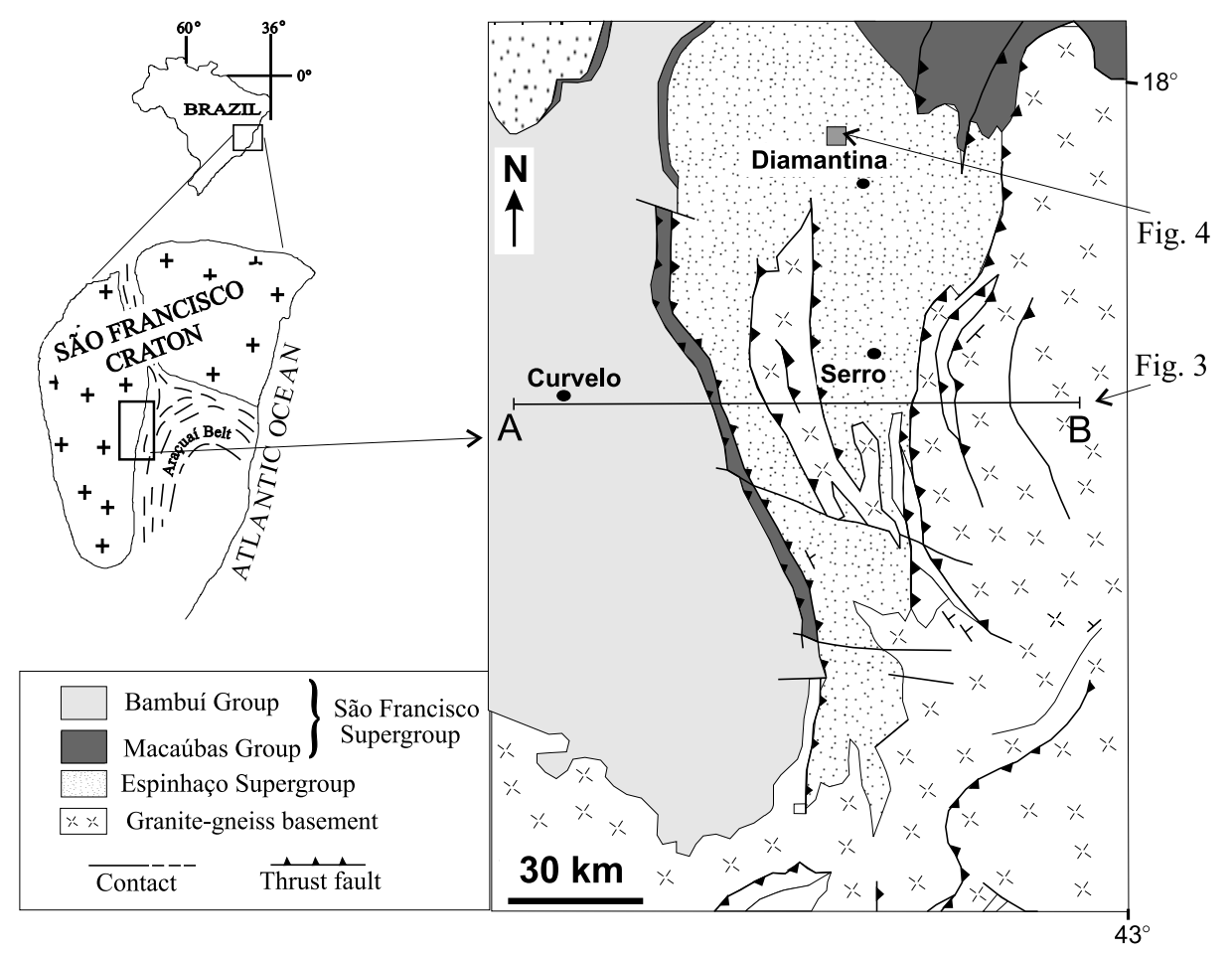

Fig. 1 - Simplified geologic-structural map of the southern Serra do Espinhaço and its setting at the São Francisco craton (modified from Schobbenhaus et al. 1984 and T.M. Dussin, unpublished data).

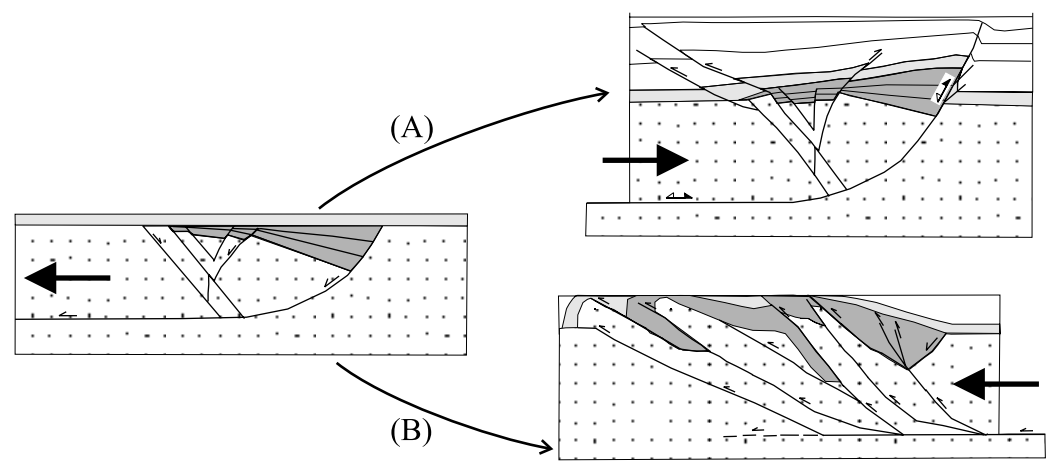

Fig. 2 - Conceptual cartoon showing (A) the classical scheme of hanging wall block inversion (McClay and Buchanan1992), and (B) the authors' idea of the southern Serra do Espinhaço footwall block inversion. Arrows indicate sense of displacement of the moving wall.

tigate the possibility of positive inversion occurring in a listric half-graben in response to the contractional displacement of the footwall block, instead of reactivating the hanging wall, as commonly proposed (e.g. McClay 1989). In recent years, many sandbox experiments have been carried out to simulate crustal rifting and extensional fault systems (e.g. McClay and Ellis 1987, Allemand and Brun 1991, Higgins and Harris 1997) as well as positive inversion tectonics (e.g. McClay 1989, Buchanan 
and McClay 1991, McClay and Buchanan 1992). These experiments show how structures progressively develop in the laboratory, providing coherent solutions and kinematic pathways that help unraveling the evolution of complex natural fault patterns.

We designed physical models to obtain new insights for the interpretation of the severely overprinted and badly exposed structural assemblage of the southern Serra do Espinhaço, where no geophysical data are available. The experiments presented here were carried out at the Laboratory of Tectonic Modeling in the Department of Geology at the Federal University of Ouro Preto. In our models, contractional translation of the footwall blocks occurred along basal detachments situated either at the same position of the listric extensional one, or at a higher level within the experimental multilayer. The latter situation represents an alternative mechanism of positive inversion for Precambrian tectonic events separated by a long period of time (more than $1.0 \mathrm{Ga}$ ). The physical reason for imposing in our experiments the upward migration of the basal detachment from extension to contraction is the supposed increase of the temperature gradient through time (McKenzie and Weiss 1975).
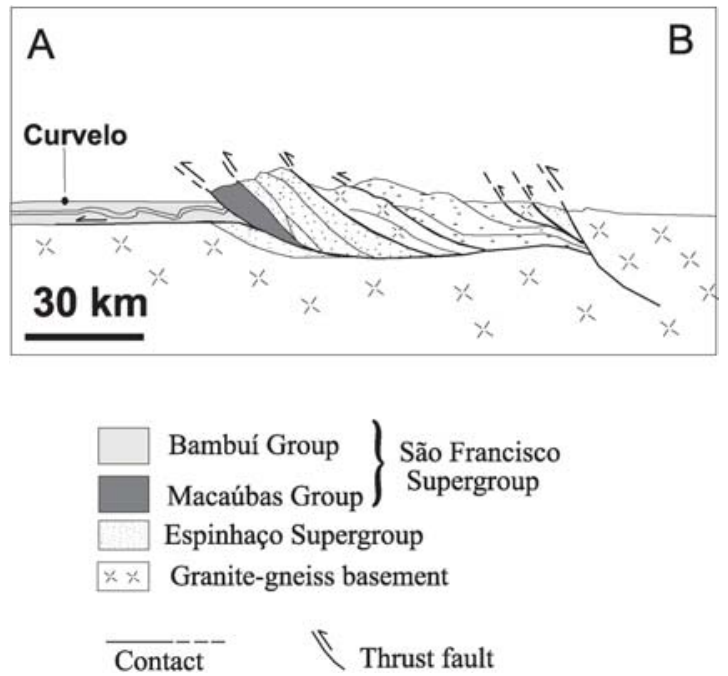

Fig. 3 - Regional W-E cross-section along the southern Serra do Espinhaço (see Fig. 1 for location) (modified after Dossin et al. 1992).

\section{THE SERRA DO ESPINHAÇO INVERSION STRUCTURE}

Several detailed geological field works on the complex stratigraphic and structural features of the southern Serra do Espinhaço have been carried out since the decade of 60 (e.g. Pflug 1965, Pflug and Renger 1973, Schöll and Fogaça 1979, A. Uhlein unpublished data, C. Schobbenhaus, unpublishded data, Dussin and Dussin 1995, Almeida Abreu 1995, Martins-Neto 1993, 1998, 2000). According to Schobbenhaus (C. Schobbenhaus, unpublished data), Martins-Neto (1993) and Dussin and Dussin (1995) the Espinhaço basin evolved between 1.7 and $1.5 \mathrm{Ga}$ as an ensialic intracratonic basin, with an initial rift stage and a subsequent flexural phase. The basin was inverted during the Late Neoproterozoic by the Brasiliano/Panafrican collisional event. According to Herrgesell and Pflug (1986), Marshak and Alkmim (1989), Uhlein et al. (1995), Silva and Toledo (1993) and Dussin and Dussin (1995), the Espinhaço Supergroup (the synrift sequence) is characterized by a strong contractional deformation with complex low-angle west-verging thrust systems. In the eastern domain of the Serra do Espinhaço, Herrgesell and Pflug (1986) and Dussin and Dussin (1995) describe a tectonic imbrication between the crystalline basement and Espinhaço sequences, which is also supported by H. Kalt, unpublished data and Alkmim et al. (1993), and caused the piling of the Espinhaço Supergroup (Fig. 3). Despite obliteration of the precontractional architecture by intense compressional deformation, the tectono-sedimentary evolution of the central part of the Serra do Espinhaço can be partially unraveled. Martins-Neto (2000) divided the tectono-sedimentary evolution of the Espinhaço rift-sag basin into prerift, rift and flexural/thermal stages. The eastward thickening of the synrift package and the predominance of eastward-directed paleocurrents (Fig. 4) in deposits related to lateraltransport systems, suggest a westward-dipping master fault located in the eastern domain of the southern Serra do Espinhaço, where thick conglomeratic 

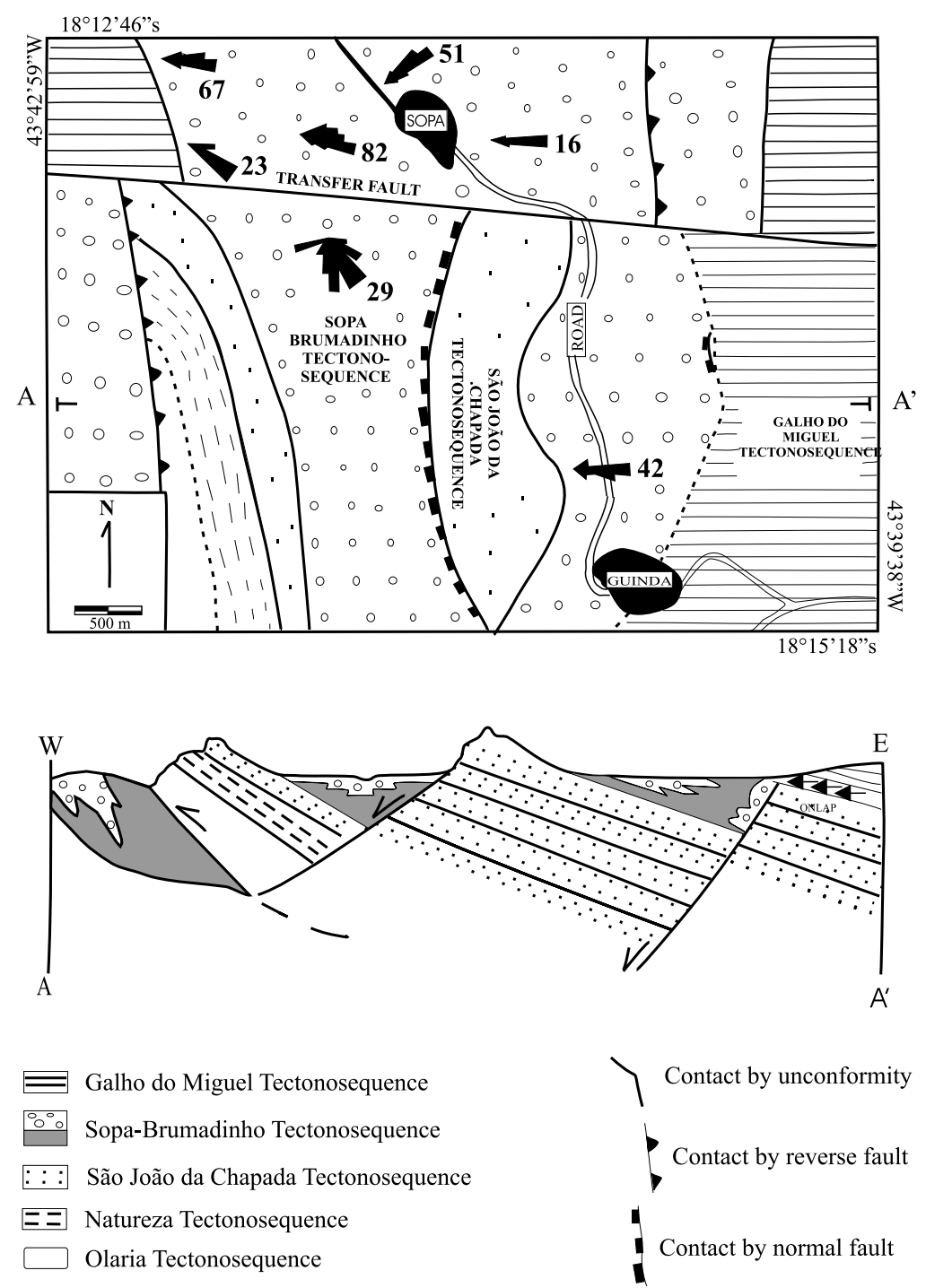

Fig. 4 - Geological map of the Espinhaço tectono-stratigraphic units of the central part of the Serra do Espinhaço (see Fig. 1 for location) showing paleocurrent rose diagrams (with numbers of measurements) for different localities, and a not-scaled cross-section (modified from Martins-Neto 2000).

successions occur. Martins-Neto (2000) also argued that the relatively thin rift sequence preserved in the western and central domains of the Serra do Espinhaço (ca. $1300 \mathrm{~m}$ thick) represents only the external portion of the synrift wedge, originally located close to the rift flexural border (Fig. 5). Evidence of linkage between this sequence and a master extensional fault is lacking.

\section{ANALOGUE MODELING}

\section{SCALING}

The technique used in this work is based on the theoretic concepts of similarity adapted to geosciences by Hubbert (1937) and on the methods described by Vendeville et al. (1987) and McClay and Ellis (1987). We used nearly cohesionless dry sand that 


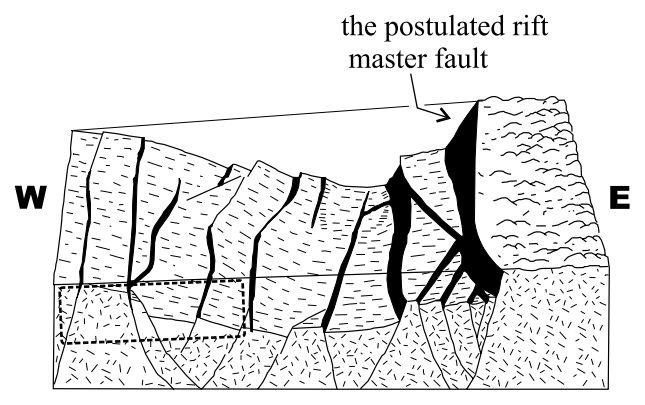

Fig. 5-Block-diagram showing the architecture of the Espinhaço rift, according to Martins-Neto (2000). Inset indicates the area where the synrift deposits occur with limited thickness in the western domain of the Serra do Espinhaço.

represents a good analogue material of upper crustal rocks since it can simulate time-independent deformation and fails according to the Coulomb-Mohr law (e.g. McClay and Ellis 1987, Davy and Cobbold 1991).

The thickness of the brittle basement, our prerift sequence, was chosen to simulate the geological situation of a graben produced in a rigid basement comparable to that of the Espinhaço Basin. We achieved the similarity in geometry by using a length ratio of $10^{-5}$, such that our $5 \mathrm{~cm}$-thick sand pack corresponds to $5 \mathrm{~km}$ in nature.

\section{EXPERIMENTAL METHOD}

Three models (experiments I, II and III) were prepared in a $30 \mathrm{~cm}$-wide deformation rig, with an initial length of $25 \mathrm{~cm}$ parallel to the transport direction and a height of $5 \mathrm{~cm}$ (Fig. 6). Each model run involved extensional deformation (Fig. 6A) overprinted by contraction. The extensional basins were inverted by moving mobile wall 2 in experiments I and II (Figs. 6B and C), and by mobile wall 1 in experiment III (Fig. 6D). In experiment I, both the extensional and contractional basal detachments were located at the same stratigraphic level. In the experiments II and III the bottom of walls 2 and 1, respectively, was elevated by $2 \mathrm{~cm}$ in order to localize the contractional detachment at a higher stratigraphic level with respect to the extensional one. In experiment III we investigate the contractional
(A) PRE-DEFORMATIONAL SET-UP

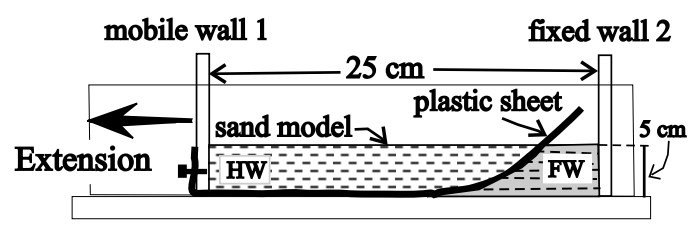

(B) EXPERIMENT I

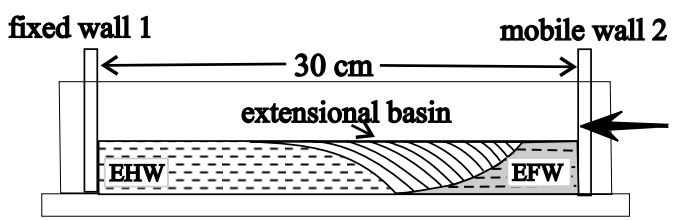

(C) EXPERIMENT II

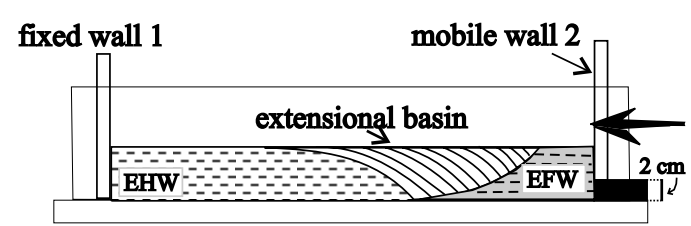

\section{(D) EXPERIMENT III}

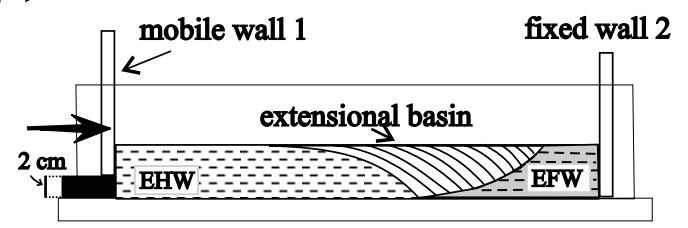

Fig. 6-Schematic illustration of the experimental apparatus. (A) The pre-deformational set-up used to simulate extension. Extension was achieved by pulling the plastic sheet attached to the mobile wall 1. (B) The inversion in the experiment I, with mobile walls in the same position (extension and inversion at the same level, contractional translation of the extensional footwall block); (C) The inversion in the experiment II, with mobile walls at different levels (extension and inversion at different levels, contractional translation of the extensional footwall block). (D) The inversion in the experiment III, with mobile walls at different levels (extension and inversion at different levels, contractional translation of the extensional hanging wall block). HW - hanging wall block; FW - footwall block; EHW - extensional hanging wall block; EFW - extensional footwall block. Arrows indicate sense of displacement of the moving wall. 
translation of the former extensional hanging wall, locating the two basal detachments at different positions.

Deformation was applied by a mobile wall driven by an electric motor at a constant velocity of $2 \mathrm{~cm} / \mathrm{h}$. The amount of stretching in step 1 was $5 \mathrm{~cm}$ in all experiments, representing $20 \%$ extension. The total amount of shortening in step 2 (i. e., basin closure) was $8 \mathrm{~cm}(27 \%), 9 \mathrm{~cm}(30 \%)$ and $15 \mathrm{~cm}$ (50\%) for experiments I, II and III respectively.

We employed dyed and sieved dry quartz sand (average grain size $200-300 \mu \mathrm{m}$ ), with an internal friction angle of $34^{\circ}$ (Gomes et al. 1998). The sand pack used in the models contained a succession of 16 dyed layers to help visualization of the individual structures and to highlight deformation. Extension was accompanied by synchronous sedimentation in the graben using sand layers of new colors. In all the experiments, a plastic sheet was introduced in the experimental box before the deposition of the sand pack, in order to impose the location and geometry of the listric normal fault. The plastic sheet was attached to mobile wall 1 and partly covered the model base (Fig. 6A). The other sheet end was carefully molded during deposition of the sand to achieve a curved geometry. The dip of the extensional ramp was about $60^{\circ}$, as commonly observed in nature. After completion of the extension, the plastic sheet was detached from the mobile wall 1 and removed prior to the inversion process. To remove the plastic sheet we pulled it carefully without causing any damage to the sand pack.

Photographs of the evolving structures were taken at regular intervals through the transparent sidewalls. At the end of each experiment, the models were wetted and sections were sequentially cut, parallel to the tectonic transport direction, to analyze possible distortion of deformation at the sidewalls. These sections have shown that friction between the sand and the glass sides causes a minor slip of the fault-blocks at the sidewalls than in the sand pack center. Since the overall structural architecture is comparable, we present photographs taken at the sidewalls.

\section{EXPERIMENT LIMITS}

Our experiments did not account for compaction and thermal effects, as well as for the flexural and isostatic response of the lithosphere. Pore fluid pressure effects were also not considered in present study even though Cobbold et al. (2001) demonstrated that the style of deformation in sandboxes could be partially controlled by the amount of fluid pressure. Our experimental multilayers did not include competence contrasts that are typical of the upper crust. Finally, it has to be emphasized that our work concerns simulation of Proterozoic deformation, where uncertainties about deformation processes and rock mechanics are still greater than in the Phanerozoic time (Marshak 1999). All the above mentioned limitations, despite being important, are shared with most analogue modeling works (e.g. Buchanan and McClay 1991, Allemand and Brun 1991, McClay and Buchanan 1992). Our simplified approach is justified by the purpose of providing basic guides for the understanding of inversion tectonics when contractional displacement is applied to the footwall block. Keeping the experiments as simple as possible allowed us to avoid additional complications not directly related to the basic tectonic process under investigation.

\section{EXPERIMENTAL RESULTS}

\section{EXPERIMENT I}

In experiment I, extension started with a gentle flexure in the hanging wall (Fig. 7A). Stretching of $12 \%$ produced a well-developed rollover anticline with a crestal collapse graben system including antithetic and synthetic faults (Fig. 7B). The curvature of the rollover anticline increased with progressive extension and faulting propagated towards the listric normal fault (Fig. 7C).

The early stages of inversion (16\% of shortening) produced horizontal tectonic compaction of the formal extensional architecture. The deformable backstop was vertically stretched and both the listric master normal fault and the synthetic faults were steepened. In addition, the rollover anticli- 

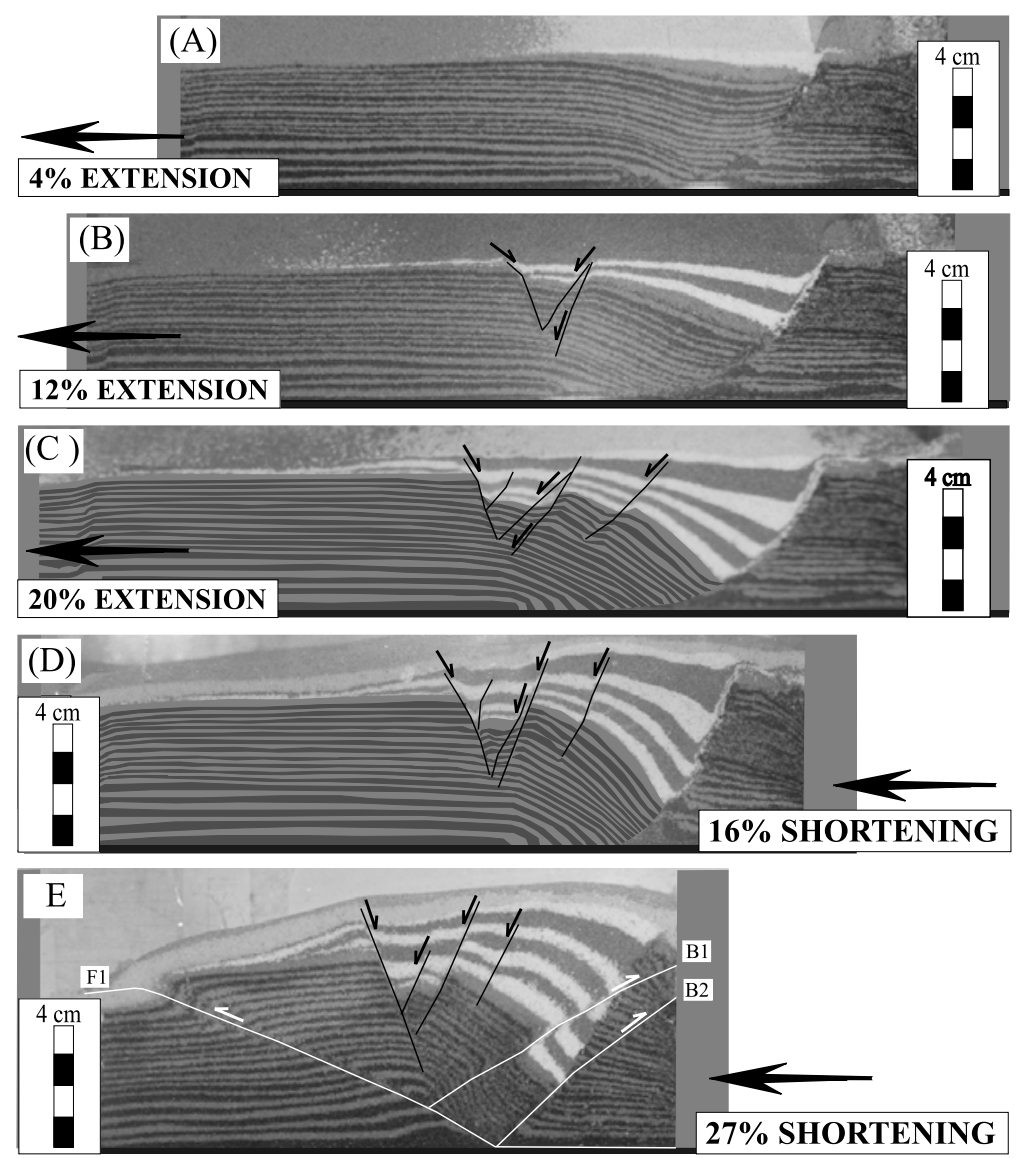

Fig. 7 - Photographs illustrating successive stages of experiment I. (A) to (C) are cross-sections of the extension, and (D) to (E) of the inversion stage. Note, in the extensional stage, the progressive formation of a rollover anticline with a crestal collapse graben in the extensional hanging wall, and, in the inversional stage, the development of a new thrust system in the pre-rift sequence. F- forethrust; Bbackthrust; numbers indicate thrust formation order. Black lines outline the traces of the crestal collapse graben normal faults and white lines the traces of the new thrust faults.

nal curvature accentuated (Fig. 7D). The progressive shortening caused the development of one major forethrust and two backthrusts (Fig. 7E). Those structures propagated, respectively, into the extensional hanging wall and footwall, cutting the old master normal fault. The uplift associated with inversion was slightly asymmetric since it concentrated above the backthrusts. No reactivation of synrift antithetic and synthetic faults occurred until the final stage of inversion (27\% of shortening).

\section{EXPERIMENT II}

The extensional architecture in experiment II was similar to experiment I, since boundary conditions were the same (Fig. 8A). In the early stages of inversion (Fig. 8B), a thrust flat (fault F1) was produced by the moving wall 2 and the upper ramp segment of the listric normal master fault underwent counterclockwise rotation. The translating extensional footwall (the deformable backstop) was first verti- 
cally stretched (Fig. 8C) and then pushed upwards. At $16 \%$ of shortening, two forethrusts developed in the synrift sequence (F1 and F2) and one backthrust (B1) in the deformable backstop. Forethrusts cut the older normal detachment and the synthetic crestal collapse faults. The translating extensional footwall compressed the basin fill during progressive shortening, trapping its deepest domain (Fig. 8D). At highest shortening (30\%), a third forethrust (F3) developed in the prerift and cut the upper domain of the normal rollover anticline transporting a prerift sheet into the synrift sequence (Fig. 8E). No reactivation of the antithetic crestal collapse fault was observed.

\section{EXPERIMENT III}

Figure 9A shows experiment III after $20 \%$ of extension, characterized by a rollover anticline and a crestal collapse graben structure that compare well with those in experiments I and II. After $16 \%$ of shortening (Fig. 9B) inversion produced slightly asymmetric uplift of the extensional hanging wall block with two blind forethrusts (F1 and F2) and a well developed backthrust (B1). The antithetic crestal collapse graben fault (C1) was passively rotated, causing tightening and slight uplift of the collapse graben infill. The increasing contractional deformation (33\% of contraction, Fig. 9C) produced strong vertical strain in the extensional hanging wall with counterclockwise rotation and reactivation of faults F1 and F2. The oldest thrust fault (F1) accommodated the highest displacement, cutting the normal crestal collapse fault $\mathrm{C} 1$ and connecting to the former extensional fault $\mathrm{C} 3$. Fault $\mathrm{C} 3$ was reactivated as a thrust fault and translate part of synrift sediments out of the crestal collapse graben. In addition, a new backthrust (B2) formed in the hinterland and, in the foreland, synthetic crestal collapse fault $\mathrm{C} 2$ became reactivated as a thrust fault (F3).

Figure 8D shows the deformation after $50 \%$ of shortening. A new forethrust (F4) developed and, as dislocation on the individual faults increased, shortening produced a classical antiformal stack with overlapping thrust horses and a coincident trailing branch line.

\section{DISCUSSION}

\section{Comparison Among Analogue Models}

The three experiments described above show completely distinct styles of deformation (Fig. 10(A)). In experiment I, development of a major pop-uplike structure forced the whole extensional basin to uplift, with minor deformation in the basin infill. In experiment II, a forward-breaking thrust system caused the forelandward translation and uplift of the thicker part of the former extensional basin. Prerift sheets were pushed into the synrift sequence. The differences shown by models I and II, in the inversion stage, are a direct consequence of the compressional basal detachment position. Its location at the base of the sand pack produced, in experiment I, the nucleation of the first thrust ramp (1) below the basin sequence. In experiment II, the higher location of the basal detachment caused thrusting to nucleate in the interior of the synrift sequence, adjacent to the listric ramp of the master extensional fault. The younger thrusts cut syn- and prerift sequences.

In experiment III, the former extensional basin was trapped by an antiformal stack. As in experiment II, positive inversion transported prerift sheets into the synrift sequence. The differences shown by models II and III are related to the thrust system geometry, an imbricate thrust system and an overlapping ramp anticline which produced an antiformal stack with increasing displacement, respectively. According to Gomes and Ferreira (2000), an antiformal stack forms in sandbox models when the regular forward development of a foreland vergent thrust system is inhibited. This impediment may be related either to the presence of an obstacle in the foreland, or to a high friction along basal detachment. In our experiment III, the extensional footwall with the high angle rift master fault seems to represent the obstacle to the propagating thrust system. In contrast, the formation of a forward-breaking thrust system in experiment II was facilitated by the lowangle geometry of the upper rollover anticline in the extensional hanging wall and by the nearly parallel dip of synrift layers and thrust faults (Fig. 9D). 

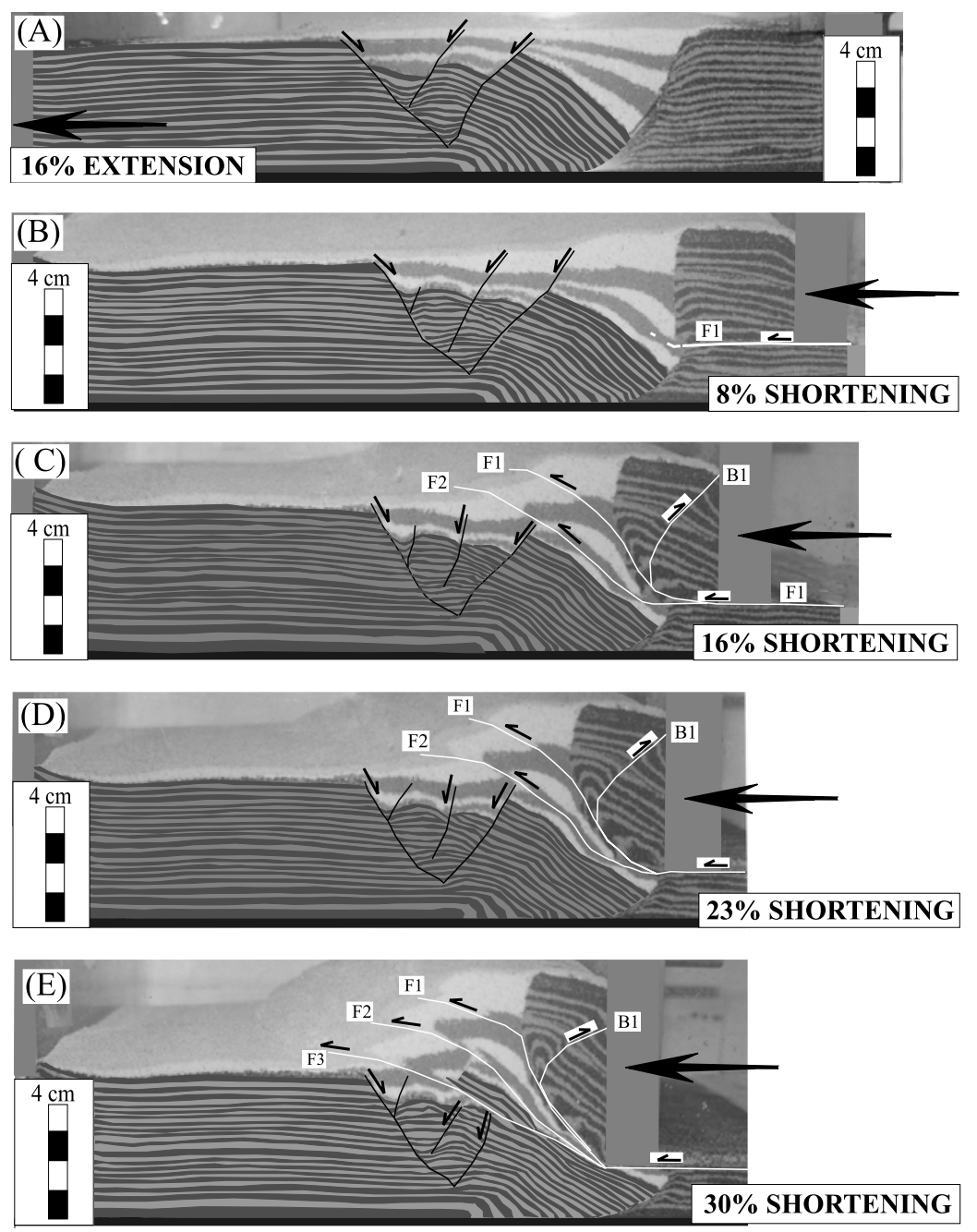

Fig. 8 - Photographs illustrating successive stages of experiment II. (A) presents a rollover anticline with a crestal collapse graben, similar to that of experiment I; and (B) to (E) the sequential inversion. In the inversional stages, note the progressive counterclockwise rotation of the listric detachment and the development of a new thrust system. F- forethrust; B- backthrust; numbers indicate thrust formation order. Black lines outline the traces of the crestal collapse graben normal faults and white lines the traces of the new thrust faults. The synrift sequence is represented by light gray and white layers.

\section{Comparisons With Previous Analogue Models}

Extensional geometries produced in our models compare well with those obtained by McClay and Ellis (1987), which were set up with a rigid footwall. In all experiments, the extensional basin was characterized by classic rollover anticlines and crestal collapse graben structures.
Analogue models of listric fault basin inversion have been carried out by McClay (1989) and McClay and Buchanan (1992), who simulated the basin closure by reversing the hanging wall motion (Fig. 10(B)). In their models, the main extensional detachment is always reactivated. Footwall shortcut thrusts and hanging wall backthrust may develop. In addition, reactivation of the crestal collapse graben 

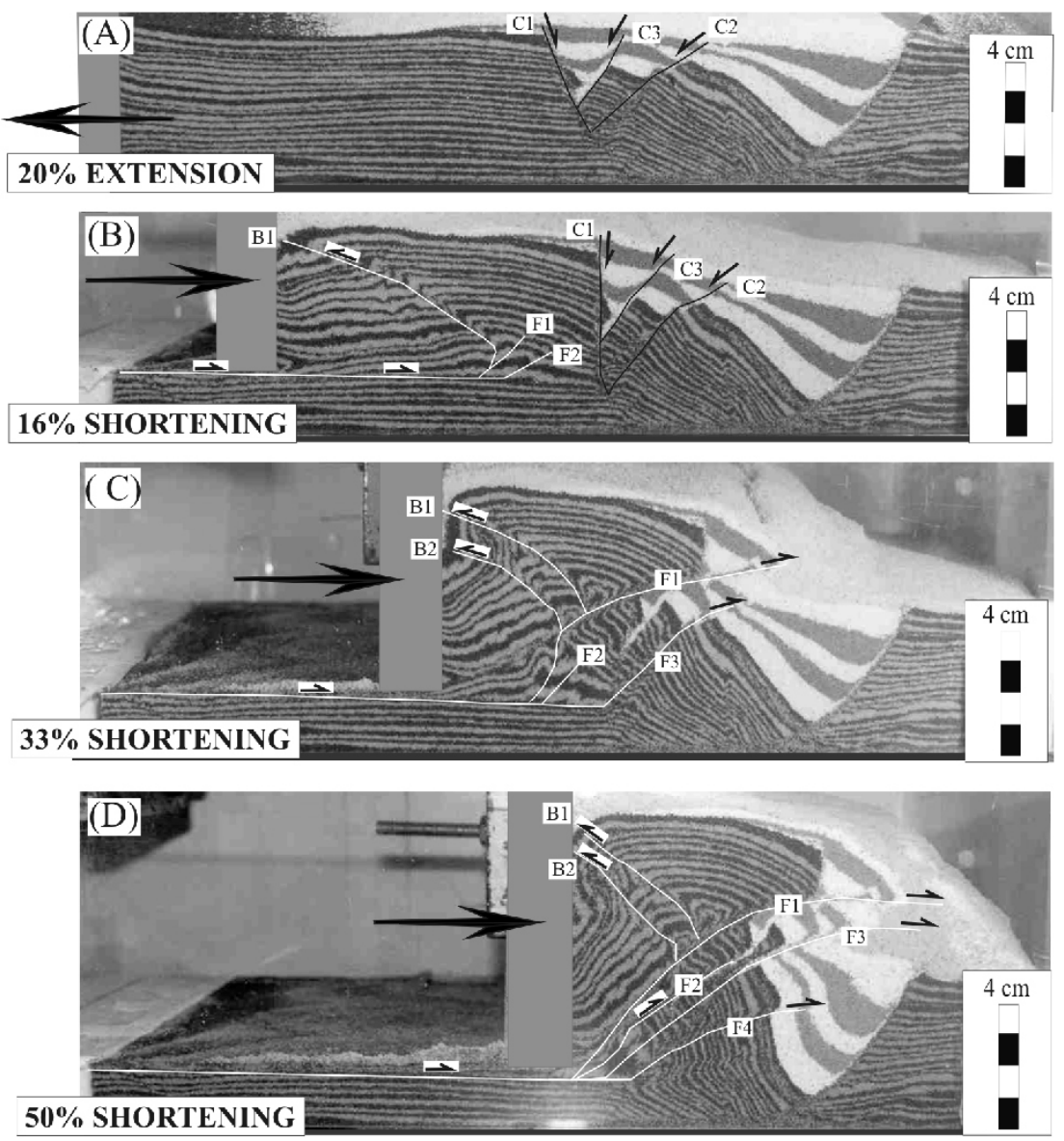

Fig. 9 - Photographs of experiment III. (A) presents a rollover anticline with a crestal collapse graben, similar to that of experiment I; and (B) to (D) the sequential inversion. Note, in the inversional stage, the sequential development of an antiformal stack. C- normal faults in the crestal collapse graben; Fforethrust; B- backthrust; numbers indicate fault formation order. Black lines outline the traces of the crestal collapse graben normal faults and white lines the traces of the new thrust faults. The synrift sequence is represented by light gray and white layers.

might be expected. The authors concluded that inversion architecture depends on the pre-existing extensional detachment geometry and the amount of basin closure. The comparison between their dip-slip inversion of a listric fault system and the experiments presented here suggests that an additional item may influence inversion-architecture: the moving fault block (Fig. 10). One of the most striking features of inversion produced in our experiments is that thrusts form a completely new thrust system.
COMPARISONS With FiEld EXAMPles Described IN THE LITERATURE

Most conceptual studies present the inversion of domino-type normal faults or listric normal faults with the inversion affecting the hanging wall block. Only a few studies have described the inversion of a half-graben by the movement of the extensional footwall (e.g. McClay et al. 1989, Butler 1989, Hayward and Graham 1989, Knott et al. 1995). Their theoretical interpretations present some fea- 

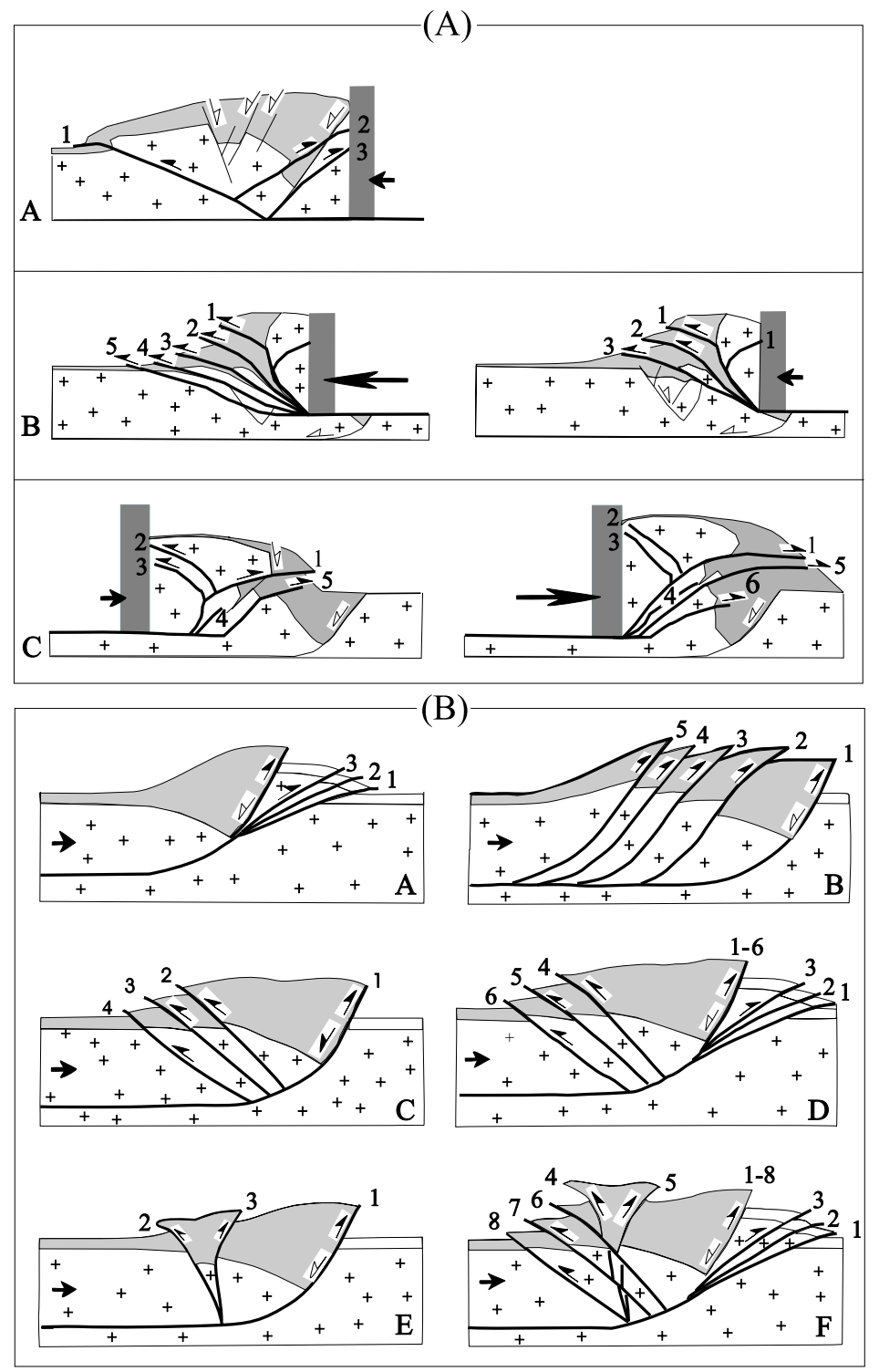

Fig. 10-Cartoons illustrating conceptual models for positive inversion. (A) Our models: A- Experiment I; B- Experiment II; and C- Experiment III (note the progressive shortening in experiments II and III). (B) The dip-slip inversion of a listric fault system presented by McClay and Buchanan (1992) (modified from McClay and Buchanan 1992): A- Imbricate fan of 'break-back' footwall shortcut thrusts; B- 'breakback bypass' thrusts; C- imbricate fan of 'forward-breaking' backthrusts; D- fan structure of backthrusts and footwall shortcut thrusts; E- crestal collapse 'pop-up' structure; and F- combined model.

tures that were also produced in our experiments, such as the trapping of the rift fills in the hinterland of the inverted basin, the development of a thrust system in the foreland and the introduction of prerift sheets into the synrift sequence. McClay et al. (1989) proposed this architecture for the McCook half-graben of the Kechika Trough, Canada (Fig. 11A), and Butler (1989) for the regional west 


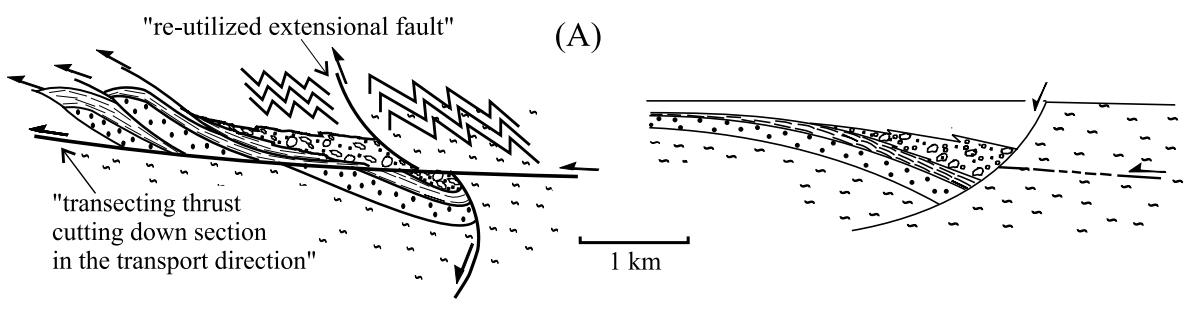

(B)

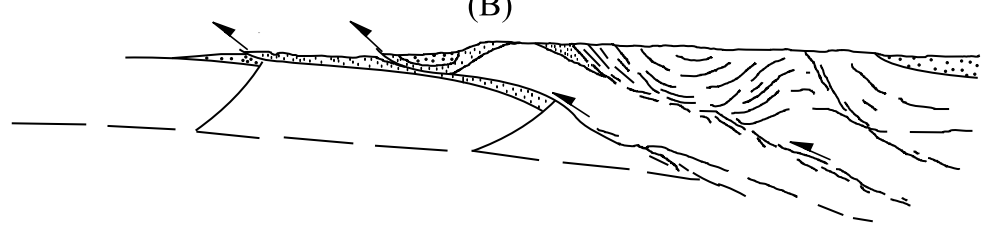

Fig. 11 - (A) The McCook half-graben of the Kechika Trough, Canada, a basin closed by the footwall of an extensional detachment (simplified from McClay et al. 1989). (B) An idealized representation of the west Alp basin, closed by the footwall of an extensional detachment (modified from Butler 1989).

Alps (Fig. 11B). Both architectures are in good agreement with our experiment II. In addition, McClay et al. (1989), Hayward and Graham (1989) and Knott et al. (1995) proposed that, during the progressive evolution of basin inversion, rotation of the normal detachment ramp occurs until complete inversion. The evolution of an "overturned normal fault" can be seen in our physical model II (Fig. 8).

INSIGHTS FOR THE EVOLUTION OF THE SOUTHERN SERRA DO ESPINHAÇO STRUCTURE

Even though analogue models are oversimplifications of natural processes, the deformation style described in our experiments may be illustrative for the Serra do Espinhaço inversion structure. Model II shows one of the most important features of the southern Serra do Espinhaço: the imbrication between basement and synrift sequences. In addition, the imbricate thrust system developed during the inversion of the extensional footwall block is similar to that found in the southern Serra do Espinhaço (Dossin et al. 1992, Alkmim et al. 1993). It supports the location of the rift master fault at the mountain range eastern domain, as proposed by MartinsNeto (2000). For a rift master fault located at the west portion of the southern Serra do Espinhaço, the frontal inversion would have been caused by the reversal of extensional hanging wall block. In this case, an anticlinal stack would have formed with high-angle fore- and backthrusts. High-angle faults, however, are only locally described in the southern Serra do Espinhaço, and a regional scale anticlinal stack is unknown.

\section{CONCLUSIONS}

Our experiments demonstrate that in a positive inversion environment, when the contractional translation occurs along a basal detachment situated at a higher level with respect to the listric extensional one, the structural pattern greatly depart from the classic inversion pattern described until now in sandbox experiments. A new thrust system forms with tectonic imbrication between pre- and synrift sequences. Contractional translation of the extensional footwall block strongly favors the development of an imbricate thrust system. In contrast, translation of the extensional hanging wall block produces an antiformal stack.

Our experiment $\mathrm{I}$ also shows that inversion produced by the contractional translation of the extensional footwall, with detachments at the same level, produces a thrust system in the pre-rift sequence with minor deformation in the synrift. 
The experiment II, with extensional and contractional detachments at different levels, and contractional translation of the extensional footwall block, represents a good analogue for the southern Serra do Espinhaço thrust-fold belt.

\section{ACKNOWLEDGMENTS}

We thank financial support from Fundação de Amparo à Pesquisa do Estado de Minas Gerais (FAPEMIG) (process CEX 2637/97). C.J.S. Gomes and M. Martins-Neto acknowledge researcher fellowships from Conselho Nacional de Desenvolvimento Científico e Tecnológico (CNPq) (processes 300487/89-4 and 300404/94-8).

\section{RESUMO}

Em experimentos de areia foi simulada a inversão positiva com o intuito de investigar os processos que governam a tectônica da Cordilheira do Espinhaço Meridional na borda sudeste do Cráton São Francisco. Analisou-se, em particular, a evolução progressiva de hemigrabens, com falha de borda lístrica, na qual o fechamento da bacia ocorreu através da translação do bloco do muro da falha mestra. Duas condições foram investigadas: (i) os descolamentos distensivos e compressivos ocorrem na mesma cota e (ii) os descolamentos situam-se em posições diferentes. Os modelos revelaram que um sistema de falhas de cavalgamento com estilo colapso da lapa se desenvolve no interior do depósito sinrift quando os descolamentos não coincidem. O imbricamento entre escamas do pré- e sinrift, nos modelos, permite esboçar uma analogia com a tectônica da porção sul da Cordilheira do Espinhaço e situar a falha de borda, mestra, que não aflora, na sua extremidade leste.

Palavras-chave: modelagem experimental, inversão tectônica, bloco do muro, Bacia Espinhaço, descolamentos em cotas diferentes.

\section{REFERENCES}

Alkmim FF, Brito Neves BB And Alves JAC. 1993. Arcabouço tectônico do Cráton São Francisco - uma revisão. In: Dominguez JML AND MISI A (Eds), O Cráton São Francisco, p. 45-62.
Allemand P AND BRUN JP. 1991. With of continental rifts and rheological layering of the lithosfere. Tectonophys 188: 63-69.

Almeida Abreu PA. 1995. O Supergrupo Espinhaço da Serra do Espinhaço Meridional (Minas Gerais): o Rifte, a Bacia e o Orógeno. Geonomos 1: 1-18.

BuChANAN PG AND MCClay KR. 1991. Sandbox experiments of inverted listric and planar fault systems. Tectonophys 188: 97-115.

BUTLER RWH. 1989. The influence of pre-existing basin structure on thrust system evolution in the Western Alps. In: COOPER MA AND Williams GD (Eds), Inversion Tectonics. Geol Soc London Spec Pub 44: 105-122.

Cobbold PR, Durand S And Mourgues R. 2001. Sandbox modelling of thrust wedges with fluidassisted detachments. Tectonophys 334: 245-258.

DAVY PH AND COBBOLD PR. 1991. Experiments on shortening of a 4-layer model of the continental lithosphere. Tectonophys 188: 1-25.

Dossin IA, Dossin TM, Charvet J And Chemale JR F. 1992. Tectonique du Protérozoique superior au sud-est du Craton São Francisco (Minas Gerais, Brazil). C R Acad Sci Paris 317-II: 629-636.

DUSSIN IA AND DUSSIN TM. 1995. Supergrupo Espinhaço: Modelo de Evolução Geodinâmica. Geonomos 1: 19-26.

Gomes CJS AND FerReIRA JE. 2000. Geometry and Kinematics of Experimental Antiformal Stacks. An Acad Bras Cienc 72: 195-217.

Gomes CJS, VieIRA JF AND SEAbra Gomes AA. 1998. O ângulo de atrito interno da areia e de misturas de areia. In: CONGRESSO BRASILEIRO DE Geologia 40, Salvador, BA, Brasil, p. 410-411.

HAYWARD AB AND GRAHAM RH. 1989. Some geometrical characteristics of inversion. In: COOPER MA AND WILliams GD (Eds), Inversion Tectonics. Geol Soc London Spec Pub 44: 17-39.

Herrgesell G and Pflug R. 1986. The Thrust belt of the Southern Serra do Espinhaço, Minas Gerais, Brazil. Zeitbl Geol Paläont 1: 1405-1414.

Higgins RI AND HaRRIS LB. 1997. The effect of cover composition on extensional faulting above re-activated basement faults: results from analogue modelling. J Struct Geol 19: 89-98. 
HUBBERT MK. 1937. Theory of scale models as applied to the study of geological structures. Geol Soc Am Bull 48: 1459-1520.

Knott SD, Beach A, Welbon AI ANd BrockBANK PJ. 1995. Basin Inversion in the Gulf of Suez: Implications for exploration and development in failed rifts. In: BUCHANAN JG AND BUCHANAN PG (Eds), Basin Inversion. Geol Soc London Spec Pub 88: 59-81.

MARShAK S. 1999. Deformation style way back when: thoughts on the contrast between Archean/Paleoproterozoic and contemporary orogens. J Struct Geol 21: $1175-1182$.

MarshaK S AND AlKmim FF. 1989. Proterozoic Contraction/Extension Tectonics of the Southern São Francisco Region, Minas Gerais. Brazil. Tectonics 8: 555-571.

Martins-Neto MA. 1993. Sedimentary evolution of a Proterozoic rift basin: the basal Espinhaço Supergroup, southern Serra do Espinhaço, region of Diamantina, Minas Gerais, Brazil. Freiburger Geowiss Beitrag 4: 1-155.

Martins-Neto MA. 1998. O Supergrupo Espinhaço em Minas Gerais: Registro de uma bacia rifte-sag do Paleo/Mesoproterozóico. Rev Bras Geocienc 28: 151-168.

Martins-Neto MA. 2000. Tectonics and sedimentation in a paleo/mesoproterozoic rift-sag basin (Espinhaço Basin, southeastern Brazil). Precambr Res 103: 147-173.

MCCLAY KR. 1989. Analogue models of inversion tectonics. In: COOPER MA AND WILliams GD (Eds), Inversion Tectonics. Geol Soc London Spec Pub 44: 41-59.

MCClay KR AND BUChanAn PG. 1992. Thrust faults in inverted extensional basins. In: MCCLAY KR (Ed), Thrust Tectonics, p. 93-104.

MCClAy KR AND ElLIS PG. 1987. Analogue models of extensional fault geometry's. In: COWARD MP ET AL. (Eds), Continental Extensional Tectonics. Geol Soc London Spec Pub 28: 109-125.
MCClay KR, Insley MW and Anderton R. 1989. Inversion of the Kechika Trough, Northeastern British Colombia, Canada. In: Cooper MA AND Williams GD (Eds), Inversion Tectonics. Geol Soc London Spec Pub 44: 235-257.

McKenzie D And Weiss N. 1975. Speculations on the thermal and tectonic history of the earth. Geophys $\mathbf{J}$ Royal Astron Soc 42: 131-174.

Pflug R. 1965. A geologia da parte meridional da Serra do Espinhaço e zonas adjacentes. Rio de Janeiro, DNPM/DGM. Boletim 226: 51.

Pflug R AND RENGER FE. 1973. Estratigrafia e evolução geológica da margem SE do Cráton Sanfranciscano. In: Congresso Brasileiro de GeoloGIA 27, Aracajú, SE, Brasil, p. 5-19.

Schobbenhaus C, CAmpos DA, Derze GR AND Asmus HE. 1984. Mapa geológico do Brasil e da Área Oceânica Adjacente, Ministério das Minas e Energia/Departamento Nacional da Produção Mineral, Brasília, $501 \mathrm{p}$.

SCHÖLl WU AND FOGAÇA ACC. 1979. Estratigrafia da Serra do Espinhaço na região de Diamantina. In: Simpósio Geologia Minas Gerais (1). Boletim 1: 55-73.

Silva RR AND Toledo CLB. 1993. A Proterozoic duplex thrust system in the southern Serra do Espinhaço, Minas Gerais, Brazil. Zeitbl Geol Paläont 1: $55-66$.

Uhlein A, Trompette R And Egydio-Silva M. 1995. Rifteamentos superpostos e tectônica de inversão na borda sudeste do Cráton São Francisco. Geonomos 1: 99-107.

VendeVille B, Cobbold PR, Davy P, BRun JP And Choukroune P. 1987. Physical models of extensional tectonics at various scales. In: CowARD MP ET AL. (Eds), Continental Extensional Tectonics. Geol Soc London Spec Pub 28: 95-107. 